\title{
Medical Officers of Health, Gender and Government Responses to the Problem of Cancer in Britain, 1900-1940
}

\author{
JOSEPH MELLING and PAMELA DALE*
}

\section{Introduction: Historians, Public Officials and Cancer}

International efforts to maintain and improve the physical and mental condition of mothers, workers and warriors have often figured in national campaigns to raise human efficiency. Such concerns formed an important setting for the renewed interest in cancer at the beginning of the twentieth century, as a "medical, social, economical and political issue". ${ }^{1}$ These features of national cancer debates during the twentieth century have attracted notice in important recent research on the subject. Scholars have noted the tendency of contemporaries to deploy metaphor to depict both the disease and attempts at cure. Contemporary rhetoric frequently portrayed the battle against cancer as a national crusade of embattled peoples, winning international recognition for their heroic efforts to confront a terrible scourge. ${ }^{2}$ Historians have similarly inclined towards vivid images in depicting the progress of medical approaches to cancer. For Patrice Pinell "the organized fight against cancer" relied on the convergence of both the medical profession's various interests in the disease and the emergence of groups, separate from the scientific societies, keen to combat cancer on a number of fronts. ${ }^{3}$ In the British case, royal patronage for cancer charities has also been historically important. ${ }^{4}$ While there are parallels with professional and popular responses to other public health problems, Pinell has argued that internationally the evolution of cancer policy drew its distinctive features from the specific character of the disease itself. ${ }^{5}$

The present article addresses and extends this significant research. Broadly agreeing with Pinell's conclusions, we revise and also problematize the narrative of cancer treatment and service administration which he provides. In particular, it is argued here that a

(C) Joseph Melling and Pamela Dale 2009

* Prof. Joseph Melling, and Pamela Dale, PhD, Centre for Medical History, University of Exeter, Amory Building, Rennes Drive, Exeter EX4 4RJ, UK.

The research on which this article is based was funded by the Wellcome Trust (grant number 074999 to Pamela Dale for the project 'The Medical Officer of Health and the organization of health visiting as a comprehensive community health service,

1906-1974') and the University of Exeter. John Stewart read an early draft and offered valuable comments. We are grateful to Ornella Moscucci, John Pickstone and the referees and editors of Medical History for their helpful criticisms in revising this article for publication.

\footnotetext{
${ }^{1}$ Patrice Pinell, 'Cancer', in Roger Cooter and John V Pickstone (eds), Medicine in the twentieth century, Amsterdam, Harwood Academic Publishers, 2000, pp. 671-86, on p. 671.

${ }^{2}$ Robert N Proctor, The Nazi war on cancer, Princeton, NJ, and Chichester, Princeton University Press, 1999; Patrice Pinell, The fight against cancer: France 1890-1940, London, Routledge, 2002; James Patterson, The dread disease: cancer and modern American culture, Cambridge, MA, Harvard University Press, 1987.

${ }^{3}$ Pinell, op. cit., note 1 above, p. 675.

${ }^{4}$ Richard Hough, Edward and Alexandra: their private and public lives, London, Hodder and Stoughton, 1992, pp. 298-9.

${ }^{5}$ Pinell, op. cit., note 1 above, p. 676.
} 


\section{Joseph Melling and Pamela Dale}

number of contemporary actors misunderstood the nature of the challenges posed by cancer and others sought to represent-and misrepresent- these threats and opportunities in ways which served their own interests and aspirations. In the British case, a distinct group of public health officials operating at a local level, the Medical Officers of Health (MOHs), made a concerted effort to achieve a significant role in developing cancer services. ${ }^{6}$ There were important constraints on their work, though their contribution was a significant one which has long been neglected by historians. ${ }^{7}$ In a recent assessment of the role of the $\mathrm{MOH}$ in managing cancer services, Rosa Domenech and Claudia Castañeda explore the contribution of these officials to radiation therapy, and also raise issues which are pertinent to the present article. ${ }^{8}$ The interpretation offered here differs, once again, in emphasizing the varied strategies which British MOHs devised for tackling the problem of providing cancer treatment services in the face both of external constraints and particular administrative obstacles.

Medical Officers of Health who wished to promote cancer services were able to draw upon their existing areas of expertise. ${ }^{9}$ Those officers who established a reputation for innovative approaches to public health problems and who worked for councils with a progressive commitment to investing in a variety of health services were clearly in the strongest position to take a lead in developing fresh cancer schemes. ${ }^{10}$ John Pickstone has drawn attention to the important role of the Manchester Cancer Committee, established in 1925, and of the city's Medical Officer of Health, Robert Veitch Clark, in setting up cancer research facilities. ${ }^{11}$ Other MOHs had different professional priorities and their response to cancer was shaped by a variety of local circumstances that tended to push the disease up or down a crowded public health agenda. All local authorities and their MOHs had to respond to cancer as an emerging threat to public health. They usually did this in ways that replicated their policies towards other diseases. ${ }^{12}$ Councils that had

\footnotetext{
${ }^{6}$ For recent literature reviewing the role and effectiveness of MOHs, see Barry M Doyle, 'Competition and cooperation in hospital provision in Middlesbrough, 1918-1948', Med. Hist., 2007, 51: $337-56$.

${ }^{7}$ See Barbara Clow, 'Who's afraid of Susan Sontag? Or, the myths and metaphors of cancer reconsidered', Soc. Hist. Med., 2001, 14: 293-312, for Canadian exploration of many of the obstacles to effective cancer treatment that some British MOHs were seeking to address.

${ }^{8}$ Rosa M Medina Domenech and Claudia Castañeda, 'Redefining cancer during the inter-war period: British medical officers of health, state policy, managerialism and public health', Am.J. Pub. Health, 2007, 97 (9): 1563-71.

${ }^{9}$ This argument contrasts with existing historiography that has explored the ineffectiveness of, and overloading of responsibilities onto, MOHs. Jane Lewis, What price community medicine? The philosophy, practice and politics of public health since 1919, Brighton, Wheatsheaf, 1986.

${ }^{10}$ The $\mathrm{MOH}$ in Manchester played an unusually significant role in developing cancer services, and this must be linked to his enviable reputation for
}

successful innovation across a number of public health fields. See John V Pickstone, Medicine and industrial society: a history of hospital development in Manchester and its region, 1752-1946, Manchester University Press, 1985; Niall Johnson, Britain and the 1918-19 influenza pandemic: a dark epilogue, London, Routledge, 2006, pp. 120, 140-1; Alysa

Levene, Martin Powell and John Stewart, 'The development of municipal general hospitals in English county boroughs in the 1930s', Med. Hist. 2006, 50: 3-28, p. 13; Martin Gorsky, 'The Gloucestershire extension of medical services scheme: an experiment in the integration of health services in Britain before the NHS', Med. Hist., 2006, 50: $491-512$, p. 510 .

${ }^{11}$ Manchester's Christie Hospital remains one of the few non-London institutions whose history and relationship to professional and civic interests has been seriously researched. Eileen Magnello, A centenary history of the Christie Hospital Manchester, Manchester, Christie Hospital NHS Trust in association with the Wellcome Unit for the History of Medicine, University of Manchester, 2001.

${ }^{12}$ Niemi's work documents the impact of ideologies and service traditions in a range of public 
preferred to develop statutory-voluntary sector partnerships to address tuberculosis and infant and maternal welfare, for example, also looked to the voluntary sector to provide much of the organization and funding for cancer work.

In areas where municipal enterprise was long established and well respected, councillors and officers assumed a more prominent role. The growth of local authority health services guided responses to cancer in other ways. While each public health problem possessed distinctive features and attracted attention and resources at different times, we can still discern a pattern, or recognizable signature, in the way $\mathrm{MOHs}$ and their agencies responded to different dilemmas. These responsibilities included analysis of mortality and morbidity data, liaison with scientific and medical experts, and investment in local facilities to improve diagnosis and treatment. They extended to referral arrangements to send patients to centres of expertise and excellence, public education about symptoms and treatment, and services for the terminally ill. Such provisions will be familiar to those researching tuberculosis schemes in this period, but they also had parallels with other programmes.

The origins of the MOH's engagement with the treatment and prevention of cancer lay in the activities of Edwardian local government and the tabulation of health statistics in each district. Returns for mortality and morbidity revealed a clear increase in reported cancer cases at a time when many other indicators were suggesting improvements in the health of local populations. The MOHs assumed the role of public health educators, encouraged by the Ministry of Health after 1919, to improve awareness and contribute to what Pinell suggests was the "social illusion" of the efficacy of diagnosis and early treatment, which made the "fight against cancer credible". ${ }^{13}$ The difficulty with such a strategy was not only the considerable expense involved but the risk of dispersing anticancer efforts and wasting energies on hopeless cases rather than concentrating resources on the most promising. ${ }^{14}$ There is certainly evidence that Britain's MOHs tended to respond to the limited budgets for cancer care by restating their aspirations for the enlargement of (frequently ambitious) schemes of provision. Such broad campaigns could infringe on the activities of other medical agencies, ${ }^{15}$ though in defence of the MOHs it could be said that they adopted a more universalist approach to local patients than specialist cancer organizations.

Detailed examination of the role of the $\mathrm{MOH}$ in the fight against cancer suggests some of the complexities and tensions implicit in the duties of these officers as well as the difficulties of mobilizing the different agencies in support of a unified policy. Cancer presented various kinds of challenges to distinctive organs of British government during the early decades of the twentieth century. Knowledge about the disease and the practical means of treatment were mediated by the institutional fabric of the state, and government understanding of the problem was necessarily fragmented by the peculiar and often inconsistent ways in which these public bodies worked. This division of responsibilities opened spaces for specific groups of actors and agencies to pursue their own priorities

health projects. Marjaana Niemi, Public health and municipal policy making: Britain and Sweden,

1900-1940, Aldershot, Ashgate, 2007, pp. 1-24.

${ }^{13}$ Pinell, op. cit., note 1 above, pp. 681-2.

${ }^{14}$ Ibid., p. 678.
${ }^{15}$ Jeanne L Brand, Doctors and the state: the British medical profession and government action in public health, 1870-1912, Baltimore, Johns Hopkins Press, 1965, pp. 126-31, suggests MOHs had largely failed to extend their influence at an earlier period. 


\section{Joseph Melling and Pamela Dale}

and commitments. Such fractures in policy and action did not imply an uncertain or erratic appreciation of cancer. Both government and medical personnel registered the rising national concern to tackle a disease that became the subject, for the first time, of national policy debate. ${ }^{16}$ Policy makers were concerned to map, if not fix, the boundaries of knowledge about cancer, though most public treatment and services continued to be under the control of local government. Voluntary and philanthropic agencies remained key players in the investigation of the disease and in the care of sufferers before the Second World War, again complicating institutional practices and provision of amenities across the regions. In charting the growth of cancer treatment facilities at this time, the accumulation of distinct "local knowledge" offers a useful way of understanding the co-ordinating role of the provincial MOHs. ${ }^{17}$

While emphasizing the resilience of regional variations in cancer treatment, we clearly acknowledge the importance of the Ministry of Health between 1919 and the introduction of the Cancer Act in 1939. The exigencies of war (1939-45) diffused the impact of the new legislation, though this should not obscure its significance in connecting cancer services to a regional framework of public health management. ${ }^{18}$ Before the passage of the Cancer Act, Ministry officials encouraged MOHs to develop cancer strategies, though without necessarily providing resources. By the 1930s the Ministry was presenting the $\mathrm{MOH}$ as a figure who could conciliate the competing and conflicting demands from bodies responsible for the allocation of scarce resources, including radium, and deflect the pursuit of unrealistic goals within their areas. ${ }^{19}$

It was in these efforts at cancer policy prescription that a concern with gender was expressed by state officials and medical personnel. Pinell affirms the link between ageing and the disease but reveals that it was the unusual distribution of cases across the social spectrum that challenged public health authorities traditionally concerned with the poor. ${ }^{20}$ Scholars have also identified a concern with gender and heredity when agencies assessed the risk among men as well as women of developing cancer. ${ }^{21}$ Britain's MOHs were well versed in the discussion of local cancer returns before the inter-war period but they generally displayed limited interest in the different forms of cancer suffered by women and men. It was in communications with the Ministry of Health that women's gynaecological and breast cancers were particularly noted. A number of these cases were revealed among pregnant women and new mothers passing through local maternity

\footnotetext{
${ }^{16}$ For background to science and policy making, see Anna-K Mayer, "A combative sense of duty": Englishness and the scientists', in Christopher Lawrence and Anna-K Mayer (eds), Regenerating England: science, medicine and culture in interwar Britain, Amsterdam, Rodopi, 2000, pp. 67-106.

${ }^{17}$ We are here concerned not so much with Foucault's problem of understanding knowledge and the structure of discourses as with Geertz's celebrated notion of local knowledge. See Clifford Geertz, Local knowledge: further essays in interpretive anthropology, New York, Basic Books, 1983.

${ }^{18}$ Pickstone, op. cit., note 10 above, p. 290; Rodney Lowe, The welfare state in Britain since
}

1945, 2nd ed., London, Macmillan, 1999, p. 173; Lewis, op. cit., note 9 above, p. 15.

${ }^{19}$ Growing medical amenities reflected not only professional priorities but patients' capacities to influence both the terms and outcome of medical intervention. See Paolo Palladino, 'Between knowledge and practice: on medical professionals, patients, and the making of the genetics of cancer', Soc. Stud. Sci., 2002, 32: 137-65, p. 152.

${ }^{20}$ Pinell, op. cit., note 1 above, p. 676.

${ }^{21}$ Patricia Jasen, 'Breast cancer and the language of risk, 1750-1950', Soc. Hist. Med., 2002, 15: 17-43; David Cantor, 'The frustrations of families: Henry Lynch, heredity, and cancer control, 1962-1975', Med. Hist., 2006, 50: 279-302. 
services, though the age profile of such patients would appear to offer restricted scope for an effective cancer screening programme. Yet this was the approach taken by many MOHs. By placing limited cancer programmes within existing maternity services, local and central government officers secured control of both expenditure and amenities, thereby protecting them against the encroachment and scrutiny of rival state agencies as well as external bodies. The identification of even a small number of sufferers among pregnant women and mothers served to legitimate the MOH's role among his clientele as well as for his political superiors.

The value of these provisions for the patients themselves remains less certain. Some Medical Officers and their staff sought to develop their own expertise in dealing with cancer cases. Feminist commentators have critically assessed the extension of medical power over women and the problematic role of middle-class and professional women in advocating policies which strengthened such controls. ${ }^{22}$ Cancer screening became an important reference point for debates on women's health provision. ${ }^{23}$ In a careful historical study, Ornella Moscucci considers the effectiveness of some pioneering schemes, detailing the ways in which female medical practitioners inside and outside the municipal clinics formed alliances to promote a feminist perspective on cancer, including the advocacy of radium therapy in preference to invasive surgery. ${ }^{24}$ Researchers have similarly documented the status accorded to women patients, and even female cancers, in the United States during the early decades of the century. ${ }^{25}$

Some commentators have noted the limited attention and resources devoted to cancers more specifically associated with men, such as disease of the prostrate. ${ }^{26}$ Men are also more likely to suffer from common cancers such as invasions of the lung and stomach, suggesting that the locus of cancer in parts of the distinctively male body does not adequately explain the restricted interest in men with cancer. ${ }^{27}$ The present article studies the question of men in relation to cancer treatment by briefly considering the identification and treatment of an epithelioma affecting the skin of both men and women in a

\footnotetext{
${ }^{22}$ Jennifer Dale and Peggy Foster, Feminists and state welfare, London, Routledge \& Kegan Paul, 1986, pp. 37-8.

${ }^{23}$ Sandra Morgen, Into our own hands: the women's health movement in the United States, 1969-1990, New Brunswick, Rutgers

University Press, 2002, pp. 143-5; Ann

Withorn, 'Helping ourselves: the limits and potential of self help', in Peter Conrad (ed.), The sociology of health and illness: critical perspectives, 7th ed., New York, Worth Publishers, 2005, pp. $472-81$.

${ }^{24}$ Ornella Moscucci, 'Gender and cancer in Britain, 1860-1910', Am. J. Pub. Health, 2005, 95 (8): 1312-21; idem, 'The "ineffable freemasonry of sex": feminist surgeons and the establishment of radiotherapy in early twentieth-century Britain', Bull. Hist. Med., 2007, 81: 139-63.

${ }^{25}$ Leslie J Reagan, 'Engendering the dread disease: women, men and cancer', Am. J. Pub. Health, 1997, 87: 1779-88.
}

\footnotetext{
${ }^{26}$ The different experiences of male and female cancer patients have been explored in Sarah Payne, The health of men and women, Cambridge, Polity, 2006, pp. 165-8; Mike Luck, Margaret Bamford and Peter Williamson, Men's health: perspectives, diversity and paradox, Oxford, Blackwell, 2000, pp. 6, 78-9, 224. Also Penny Kane, Women's health from womb to tomb, New York, St Martin's Press, 1991, pp. 140-2, 159-61.

${ }^{27}$ North American research confirms males disproportionately suffer from stomach and lung cancers, usually with grim prognoses compared to (say) breast cancer. Canadian cancer incidence atlas: vol. 1, Ottawa, Canada Communication Group, 1995, pp. 42-3, 54-5; and Lillian M Axtell, Lester Breslow and Henry Eisenberg, 'Trends in survival rates of cancer patients: Connecticut and California', in Tavia Gordon, Margaret Crittenden and William Haenszel (eds), Cancer mortality trends in the United States 1930-1955, Bethesda, US Government Printing Office, 1961 pp. 49-67, table 2, p. 65.
} 


\section{Joseph Melling and Pamela Dale}

variety of occupations, ${ }^{28}$ but particularly identified as a hazard in cotton textile factories. ${ }^{29}$ The incidence of this disease became strongly associated with the male machine (or "mule") spinners whose abdomen and groin were peculiarly exposed to the oil-based carcinogen in the textile mill. ${ }^{30}$ In a striking parallel with the situation of women invited to submit themselves to embarrassingly intimate medical examinations to ensure the early diagnosis (accompanied by the promise of successful treatment) of cervical cancer, the voluntary and even compulsory medical examination of spinners was presented as a way of preventing serious illness and fatalities. We consider why compulsory medical examinations were rejected by the cotton industry despite employers' anxiety to avoid compensation claims, and how a technical solution of safer oils was finally adopted. ${ }^{31}$ In this area of research and treatment, regional MOHs who often possessed considerable experience of factory and domestic conditions, were effectively excluded from the deliberations on mule spinners' cancer.

A similar pattern of exclusion is evident in the policies and practices adopted by the Ministry of Pensions in regard to former servicemen who developed cancers, possibly related to military injuries. ${ }^{32}$ The Ministry assembled a team of cancer experts who were persuaded, even more so than their counterparts in the Factory Department when dealing with mule spinners, that local physicians and agencies were liable to be overgenerous in their attribution of cancer (and hence compensation) to former wounds. Such scepticism among government officials and their experts again suggests a calculation of treatment costs versus life preservation which Pinell argues was fundamental to many deliberations over cancer. ${ }^{33}$ The possibility of compensation payments certainly figured in the correspondence of senior government officials as they sought to limit the liability of the state for disease in much the same way that industrialists resisted claims for the exposure of workers to industrial toxins. We argue here that in many arenas of industrial and state service, men were less able to attract the interest and resources of medical personnel for the identification and treatment of cancer than women, who accessed the modest maternity and child welfare services provided by municipal government. ${ }^{34}$ Even where cancers became strongly identified with men's employment and military service, there remained important political, institutional and cultural barriers to men gaining recognition and recompense for the cancers that affected them. Such distinctions and discrimination may only be adequately understood, however, within the complex and often disparate constellation of facilities which served cancer

\footnotetext{
${ }^{28} \mathrm{~S}$ A Henry discussed a number of maledominated occupations in Cancer of the scrotum in relation to occupation, London, Oxford University Press, 1946.

${ }^{29}$ Epitheliomas and chrome ulcers were a serious, widespread health problem in British industry before the 1930s. Peter Bartrip, The Home Office and the dangerous trades: regulating occupational disease in Victorian and Edwardian Britain, Amsterdam, Rodopi, 2002, pp. 283-9.

${ }^{30}$ Alan Fowler and Terry Wyke (eds), The barefoot aristocrats: a history of the Amalgamated Association of Operative Cotton Spinners, Littleborough, G Kelsall, 1987, pp. 184-96.
}

\footnotetext{
${ }^{31}$ Sir Thomas Legge, Industrial maladies, ed. S A Henry, London, Oxford University Press, 1934, pp. 12-16.

${ }^{32}$ This was a different, and obviously later, debate to that concerning cancer amongst older soldiers which had prompted investment in services by the French government in 1917-1918. Pinell, op. cit., note 2 above, pp. 67-8.

${ }^{33}$ Pinell, op. cit., note 1 above, p. 678.

${ }^{34}$ For maternalism and its contribution to state welfare, see Bernard Harris, The origins of the British welfare state: society, state and social welfare in England and Wales, 1800-1945, Basingstoke, Palgrave Macmillan, 2004, pp. 22-3.
} 
sufferers at this time. We develop these arguments by considering first the peculiar status and responsibilities of Britain's Medical Officers of Health.

\section{Medical Officers of Health and Cancer Provisions in early-twentieth-century Britain}

Knowledge about cancer has been gained historically through disciplinary research and clinical categories established by professional experts and medical authorities. It was also acquired in the course of conducting the practical activities of local and central government. This point may be illustrated by a comparison of the work undertaken by MOHs in south-west England and the West Riding of Yorkshire, and more particularly the county boroughs of Exeter and Halifax. These local authorities provided the case studies for a wider project exploring contrasting models of public health provision. Halifax provides a useful, though not well-known, example of a progressive northern council keen on municipal enterprise aimed at combating the problematic legacy of the town's nineteenth-century urban and industrial expansion. Exeter was a more conservative authority, preferring its citizens to rely on self-help and voluntary provision wherever possible and arguing that it did not have any pressing health crises. Yet Halifax and Exeter both had to acknowledge and respond to a developing sense of unease over rising cancer deaths. Neither district developed a reputation for energetic, progressive approaches to cancer services, though both recorded cancer death rates above the national average. In this respect, they offer a valuable contrast to the new initiatives pursued in Manchester and other pioneering centres which have loomed large in the established historiography and may constitute examples of patterns more common in local government. Each of our areas possessed distinctive features but in terms of socio-economic condition and local government policy are representative of many other districts. Halifax, for example, boasted a tradition of municipal enterprise but like many textile towns and manufacturing districts struggled with the legacy of health problems from its Victorian past. Devon, on the other hand, had a much older history of textile production than Yorkshire, but the pattern of cancer provision in its county town reflected the peculiar demographics of a dispersed rural population and the traditional strength of its voluntary agencies.

In tackling cancer in the early years of the twentieth century MOHs faced a dual challenge: firstly, little was known about the origins and different forms of a disease which affected a significant but indeterminate proportion of their local population; and secondly, there was little consensus on the most effective methods of prevention and treatment. Hereditary and environmental causes of cancer remained matters of considerable debate. Effective means of preventing the disease were also the subject of professional and popular press speculation. One of the most important innovations to give MOHs a leading role in communicating with the general population was the introduction of health information campaigns. ${ }^{35}$ Increased professional contacts between the MOHs and the

\footnotetext{
${ }^{35}$ Virginia Berridge and Kelly Loughlin, 'Introduction', in Virginia Berridge and Kelly Loughlin (eds), Medicine, the market and the mass
}

media: producing health in the twentieth century, London, Routledge, 2005, pp. 1-16. For related voluntary sector effort, see Ina 


\section{Joseph Melling and Pamela Dale}

wider medical community were also encouraged by the expansion of public health services and the reorganization which followed the 1929 Local Government Act. ${ }^{36}$ While MOHs rarely claimed specialist scientific knowledge or clinical expertise in the field of cancer research and treatments such as radiotherapy, their routine involvement with patients and municipal hospitals enabled them to address problems of co-ordination, particularly in regard to related epidemiological work and health propaganda which publicized the need for early diagnosis and treatment. ${ }^{37}$ In one sense the MOH's involvement with cancer began with failure: he recorded cancer deaths and continuing illness. Yet it was the rising trend of cancer deaths in a period when many other diseases were claiming fewer fatalities that drew the attention of individual officers, the Registrar General, and the wider community to the shadow cast by the dreaded disease. ${ }^{38}$

Cancer provision in Halifax developed within a framework of municipal services established since the dawn of incorporation in the $1840 \mathrm{~s} .{ }^{39} \mathrm{New}$ political alliances, notably a Lib-Lab pact that enjoyed some Conservative support on welfare issues, ${ }^{40}$ were forged in the early twentieth century and the council's renewed commitment to improved public health was complemented by the Board of Guardians' investment in St Luke's Hospital (later Halifax General Hospital). ${ }^{41}$ In the Edwardian period the Corporation was widely praised for its sanitary improvements, low death rates and imaginative schemes for personal health services. ${ }^{42}$ By the time of its 1932 public health survey, the health department oversaw an array of dispensaries, clinics, and hospitals dealing with an expanding range of clients. ${ }^{43}$ The voluntary Royal Halifax Infirmary (RHI) had also invested in new facilities, cooperating with municipal maternity and venereal disease schemes in these years, while the Corporation acted on Ministry of Health advice to support the RHI's cancer services. ${ }^{44}$ The reports of successive MOHs, J T Neech,

Zweiniger-Bargielowska, 'Raising a nation of "good animals": the New Health Society and health education campaigns in interwar Britain', Soc. Hist. Med., 2007, 20: 73-89.

${ }^{36}$ For discussion of initiation and implementation of health policy, see Sally Sheard and Liam J Donaldson, The nation's doctor: the role of the Chief Medical Officer 1855-1998, Abingdon, Radcliffe, 2006, pp. xvi-xvii and passim.

${ }^{37}$ Using tuberculosis as a case study, Worboys has discussed how MOHs' conceptions of disease, which frequently differed from those of clinicians and researchers, possibly hampered effective control measures. Michael Worboys, Spreading germs: disease theories and medical practice in Britain, 1865-1900, Cambridge University Press, 2000, pp. 1-6, 232. The problems created by the MOHs' multifaceted, but sometimes confused, response are explored in Neil McFarlane, 'Hospitals, housing and tuberculosis in Glasgow, 1911-51', Soc. Hist. Med., 1989, 2: 59-85.

${ }^{38}$ For discussion of cancer and other death rates, see Harris, op. cit., note 34 above, p. 221.

${ }^{39} \mathrm{H}$ W Harwood, 'The making of our municipality', in J J Mulroy (ed.), The centenary book of Halifax: the story of the town that bred us, Halifax, Mulroy, 1947, pp. 16-35.

\footnotetext{
${ }^{40}$ Patricia A Dawson, 'Liberalism and the challenge of Labour: the 1906 progressive election in Halifax', Trans. Halifax Antiquarian Soc., 1994, 2 (n.s.): 107-24.

${ }^{41} \mathrm{~J}$ G Washington, 'The history of the Halifax General Hospital', Trans. Halifax Antiquarian Soc., 1998, 6 (n.s.): 94-116.

${ }^{42}$ Halifax Local Studies Centre (hereafter HLS), 352 HAL, Halifax County Borough Minutes (hereafter Halifax CB minutes) 1901-1902, pp. 670-4. A report on the Royal Institute of Public Health Congress, held in Exeter in August 1902, by the $\mathrm{MOH}$ and Alderman J F Coe, Chairman of the Health Committee.

${ }^{43}$ Halifax Corporation rebutted claims of extravagance. Bernard Harris, The health of the schoolchild: a history of the school medical service in England and Wales, Buckingham, Open University Press, 1995, p. 97.

${ }^{44} \mathrm{~J}$ G Washington, 'The origins and development of the Halifax Royal Infirmary, 1807-1995', Trans. Halifax Antiquarian Soc., 1996, 4 (n.s.): 68-86. HLS; 614 HAL, Annual reports of the health of the borough (hereafter Halifax $\mathrm{MOH}$ reports), 1938, pp. 18-19, lists details of cancer services including municipal support for the RHI
} 
The Problem of Cancer in Britain, 1900-1940

Table 1

Cancer Death Rate (DR) per thousand of population in Halifax 1896-1939

\begin{tabular}{llllll}
\hline Year & Cancer DR & Year & Cancer DR & Year & Cancer DR \\
\hline 1896 & 1.1 & 1911 & 1.1 & 1926 & 1.6 \\
1897 & 0.6 & 1912 & 1.1 & 1927 & 1.6 \\
1898 & 0.6 & 1913 & 1.4 & 1928 & 1.7 \\
1899 & 0.7 & 1914 & 1.3 & 1929 & 1.7 \\
1900 & 0.7 & 1915 & 1.2 & 1930 & 1.7 \\
1901 & 0.8 & 1916 & 1.2 & 1931 & 1.9 \\
1902 & 0.8 & 1917 & 1.5 & 1932 & 1.8 \\
1903 & 1.0 & 1918 & 1.3 & 1933 & 1.6 \\
1904 & 0.8 & 1919 & 1.5 & 1934 & 1.8 \\
1905 & 1.0 & 1920 & 0.8 & 1935 & 1.9 \\
1906 & 0.9 & 1921 & 1.4 & 1936 & 1.9 \\
1907 & 1.1 & 1922 & 1.4 & 1937 & 1.8 \\
1908 & 1.0 & 1923 & 1.4 & 1938 & 1.9 \\
1909 & 0.8 & 1924 & 1.5 & 1939 & 1.9 \\
1910 & 1.0 & 1925 & 1.6 & & \\
\hline
\end{tabular}

${ }^{a}$ Halifax MOH report for 1925 , p. 14 for 1896-1925 figures, then updated annually.

Cyril Banks and George C F Roe, reflected a continuing concern to identify the epidemiology of the disease as a foundation for effective prevention and treatment. In the Edwardian period Neech had regularly reported to his health committee the conclusions of papers presented to the annual congresses of the Royal Sanitary Institute and the Royal Institute of Public Health. ${ }^{45}$ Yet the evidence suggests that development of Halifax's cancer services lagged behind the emergence of concern with the data, although the figures painted a bleak picture of continuing mortality, whether expressed as an annual total (the preferred method in Exeter), or cancer death rate (recorded in Halifax). Simple comparisons with both national rates and year on year trends were required after 1925 by the Ministry of Health. In Halifax this re-ordering of material gave new emphasis to several health problems, including cancer. ${ }^{46}$

In their collation of these statistics, successive Halifax MOHs noted a broad equality of male and female fatalities. In 1937 the same number of men and women (eightynine) died from "malignant disease", as cancer was frequently termed, in the town. ${ }^{47}$ Stomach cancer accounted for the largest number of fatalities, though in his own commentary Roe placed greater emphasis on the distinctive maladies affecting women

radium clinic run in conjunction with the Royal Infirmary, Bradford. The clinic was first referred to in the MOH report for 1932, although a discussion on the use of radium to treat cancer of the cervix appeared in 1930. Halifax MOH reports for 1930, p. 25, and 1932, p. 20. National Archives, Kew (hereafter NA) MH 66/1071, Halifax County Borough Public Health Survey Report by Dr D J Williamson (hereafter Halifax PH Survey), paragraphs 1079, 1080 and 1100.

\footnotetext{
${ }^{45}$ Report on RIPH Congress, op. cit., note 42 above, mentioned an address by Professor Sims Woodhead "dealing with the needs and requirements of to-day, in prosecuting the study of the nature and cause of cancer, infectious diseases generally, and allied subjects".

${ }^{46}$ Halifax MOH report for 1925, pp. 14-15, following format introduced by circular 648 .

${ }^{47}$ Halifax MOH report for 1937 , pp. $20-1$.
} 


\section{Joseph Melling and Pamela Dale}

with cancer of the uterus, breast and ovary, which together accounted for two fifths of female cancer fatalities. He pointed up the contrast between the invasion of women's "special organs of generation" and male susceptibility to cancers of "the food tract". 48

The peculiar association of cancer with women's reproductive and men's digestive systems offered some leverage for an iteration by Halifax's MOHs, in common with others, of a need to prioritize prevention and early diagnosis over the later treatment of mature tumours. In publicity campaigns which were comparable to its earlier approach to tuberculosis, Halifax alerted its citizens to possible risk factors and early symptoms. The 1925 effort, described in Cyril Banks' Report, included posters offering "helpful hints on cancer", again intended particularly to alert women to the need to detect breast lumps and unusual bleeding. One passage noted men's exposure to industrial cancer, but all patients were urged to consult their own doctors if they suspected signs of the disease. Citizens were sternly warned against quackery and a misplaced hope that cancer could be "cured by post". 49 Yet specialist services for sufferers emerged only slowly. Identifying cases was part of the problem but the prohibitive costs of treatment threatened municipal budgets. Following the reorganization of Poor Law medical services after 1929, local authorities faced rising costs of public health care in their districts. In the 1930s voluntary hospitals such as the RHI and its equivalent in neighbouring Bradford also urgently sought fresh sources of funding for cancer treatment equipment. ${ }^{50}$ Cancer services were developed within a restricted framework of civic funding and voluntary sector finance before the 1939 Cancer Act became law.

Financial considerations likewise shaped the development of cancer services in southwest England, where duplication of effort also became apparent. The Ministry of Health favoured the development of a co-ordinated regional service based in Plymouth and supported by all the local authorities in Devon and Cornwall. Ministry officials consistently referred to this scheme in the public health surveys of the relevant county and county borough councils conducted following the 1929 Local Government Act. ${ }^{51}$ In theory the regional scheme enjoyed the support of all the local authorities, but individual councils came under pressure to support the radium ambitions of their local hospital and associated medical community. Cornwall County Council in particular found it difficult to abandon a separate commitment to cancer services at the Royal Cornwall Infirmary. ${ }^{52}$ This local interest, and other difficulties associated with the location and staffing of any regional cancer service, meant that the proposed regional scheme had been shelved

\footnotetext{
${ }^{48}$ Among the 178 deaths registered, stomach cancer claimed 26 males and 12 females, while cancer of the uterus caused 21 deaths, breast 9 and ovary 6. Only four cancer deaths (three prostrate and one urethra) were identified as diseases of male organs. In 1932 a single scrotal cancer death was recorded, with two more in 1933. Halifax $\mathrm{MOH}$ reports for 1932, pp. 20-1, and 1933, pp. 20-2.

${ }^{49}$ Halifax MOH report for 1925 , pp. 14-15.

${ }^{50}$ Gary Firth, Bradford charity and the public purse: a history of Bradford hospitals from 1780, Bradford, Bradford Hospitals NHS Trust, 2001, pp. $45-52$.
}

\footnotetext{
${ }^{51}$ NA, MH 66/30, Cornwall Public Health Survey Report (hereafter Cornwall PH survey), 1931; NA, MH 66/58, Administrative County of Devon, Public Health Survey Report (hereafter Devon PH survey) by Allan C Parsons, 1931; NA, MH 66/608, Exeter CB, Public Health Survey, sec 1041929 GA by Dr A C Parsons, 1930 (hereafter Exeter PH survey 1); NA, MH 66/611, Exeter County Borough-further survey report by Dr Allan C Parsons, 1935 (hereafter Exeter PH survey 2); NA, MH 66/818, Plymouth CB, Public Health Survey, 1930.

${ }^{52}$ Cornwall PH survey, p. 58.
} 
though not abandoned even before it was discussed by visiting Ministry officials in the years $1930-35 .^{53}$

The regional cancer scheme did, however, remain the preferred option for at least some of the actors involved. As late as 1943 Exeter's MOH, Dr G B Page, drew on plans developed in the 1920 s to outline a post-war regional cancer service, claiming that a "comprehensive scheme for the diagnosis and treatment of cancer" was still under active consideration in the city. ${ }^{54}$ Lacking such a service, many councils had been compelled to make alternative arrangements for their cancer patients during the 1930s: public health surveys revealed that such patients were being maintained in a variety of south-west institutions, some as far away as Bristol and London. ${ }^{55}$ While rate-funded regional cancer facilities remained limited, there were substantial voluntary services in the south-west, resulting in the acquisition and use of what the Ministry viewed as significant stockpiles of radium by different institutions. ${ }^{56}$ There appeared to be limited co-ordination and some competitive rivalry within this sector, deplored by one Ministry official as a "wasteful and expensive dissipation of radium energy". He proposed that local agencies conform to a national policy of designating one centre "with better facilities for all forms of treatment" as an aid to efficiency and economy. ${ }^{57}$ In the vacuum created by the absence of a regional scheme, such an approach was undermined by the piecemeal interim arrangements devised by different local authorities for their patients.

The failure to co-ordinate services and to invest in a single unified cancer scheme in south-west England was probably representative of limitations recorded elsewhere in this period. These limits evident in the south-west can be attributed to three related factors. Local authority health departments, with the exception of Plymouth, were weak and poorly funded compared with their municipal counterparts in industrial towns such as Halifax. Another point of contrast may be found in the size and prestige of the local medical community. Ministry officials were concerned about the lack of well-qualified medical practitioners in Halifax and encouraged municipal services to draw in expertise from elsewhere, thereby undermining local practitioners' ability to shape emerging provision. ${ }^{58}$ In Devon, doctors, who enjoyed strong professional and personal reputations, and had a tradition of working effectively together, were in a better position to defend their own interests and those of the voluntary hospitals from municipal encroachment. ${ }^{59}$ Powerful doctors and weak municipalities created an opportunity for an influential but disparate voluntary sector keen to invest in local treatment facilities for cancer patients. These lay and medical philanthropic entrepreneurs were instrumental in the amassing and stockpiling of

\footnotetext{
${ }^{53}$ Ibid.

${ }^{54}$ West Country Studies Library, Exeter, Exeter MOH report for 1943 by G B Page, p. 25 .

${ }^{55}$ Some examples are given in Exeter PH survey

1, pp. 55-9; Devon PH survey, pp. 47-58; and

Cornwall PH survey, pp. 58-9.

${ }^{56}$ Devon PH survey, pp. 31-2, listed radium provision at the Royal Devon and Exeter Hospital, and at hospitals in Torquay, Newton Abbot, and Totnes, as well as at the
}

East Devon and West Cornwall Hospital in Plymouth.

${ }^{57}$ Devon PH Survey, pp. 31-2.

${ }^{58}$ Halifax PH survey, paragraphs $925-6$ and 994-5.

${ }^{59}$ Martin Powell, 'Coasts and coalfields: the geographical distribution of doctors in England and Wales in the 1930s', Soc. Hist. Med., 2005, 18: 245-63, pp. 256-7; Ian R Whitehead, Doctors in the Great War, London, Leo Cooper, 1999, pp. 34, 47. 


\section{Joseph Melling and Pamela Dale}

radium, and their success in this enterprise attracted admiration as well as criticism in the public health surveys. Ministry officials saw a definite role for the voluntary sector but also clearly expected the MOHs to lead and co-ordinate the development of cancer services and other public health programmes. There was particular concern about the delivery of maternity and child welfare services in Exeter, with officials perplexed at the capacity of female activists to exert an influence which rightly (in London's view) belonged to the MOH. ${ }^{60}$ The inevitable consequence of this competitive and unco-ordinated approach to cancer treatment was a fragmentation of limited provisions for sufferers.

Amid these particularistic and often cumbersome arrangements for dealing with cancer patients, the MOHs and even Ministry officials were none the less able to find hopeful signs of progress during the inter-war years. ${ }^{61}$ In 1934 Exeter's public health committee gave its $\mathrm{MOH}$ the power to assist poorer cancer patients, leading to some relief for lung cancer sufferers, although radium treatment remained elusive outside the Royal Devon and Exeter Hospital (which held a radium stock), despite the National Radium Institute being based in Bristol. ${ }^{62}$ It was also evident that public health education was weak in Exeter and that both Cornwall and Devon were also reluctant propagandists, showing little enthusiasm for disseminating information given in Ministry circulars or sustaining public awareness beyond the annual "health week". ${ }^{63}$ One justification given for the limited pace of change was that Exeter was free from "cancer-producing industries", which meant most advice was incidentally offered to women who attended maternity and child welfare centres. ${ }^{64}$ Yet evidence from Exeter (Table 2) revealed a stubborn persistence, if not a rising trend, of cancer deaths (not differentiated by type) during the 1930s and a noticeable increase during the war years (1939-45). ${ }^{65}$

Table 3 indicates that Exeter had a higher rate of cancer deaths in 1929 than Halifax, and there was also concern about cancer deaths in the areas served by Devon and Cornwall County Councils. It is, therefore, not surprising that the incidence of cancer and arrangements for its diagnosis and treatment featured in all their public health surveys. The approach to the problem was however quite different to that in Halifax. In the south-west of England, Ministry officials were critical of service delivery but tended to accept the MOHs' view that climate and industries were generally conducive to health and any analysis of health indicators (especially cancer, but also tuberculosis) had to take account of the region's retirement communities and health tourists. ${ }^{66}$ Without detailed evidence to the contrary there was some acceptance of the view that an ageing population lay behind the high and rising number of cancer deaths. This was not the interpretation adopted in Halifax, where cancer deaths in the inter-war period were part of what had become a high overall

\footnotetext{
${ }^{60}$ Exeter PH survey 1, pp. 7-8, 32-5, 60.

${ }^{61}$ The re-survey of Exeter provision was more positive about potential developments but regretted the absence of a definite scheme for "the ascertainment of people suffering from cancer". Exeter PH survey 2, pp. 44-5,

${ }^{62}$ Ibid.

${ }^{63}$ Cornwall PH survey, pp. 58-9; and Devon PH survey, pp. 37-8.
}

\footnotetext{
${ }^{64}$ Exeter PH survey 2, pp. 44-5.

${ }^{65}$ This was discussed with the $\mathrm{MOH}$ who tentatively linked the increase in "pulmonary carcinoma" to "tarred roads", Exeter PH survey 2, p. 44.

${ }^{66}$ These points in relation to cancer receive particular attention in Devon PH survey, p. 10, and a more general discussion appears in Exeter PH survey 1, pp. 3-5, 9-10.
} 
The Problem of Cancer in Britain, 1900-1940

Table 2

Total Cancer Deaths recorded in Exeter 1916-1945

\begin{tabular}{lccc}
\hline Year & Cancer Deaths & Year & Cancer Deaths \\
\hline 1916 & 84 & 1931 & 96 \\
1917 & 67 & 1932 & 116 \\
1918 & 80 & 1933 & 108 \\
1919 & 79 & 1934 & 121 \\
1920 & 83 & 1935 & 127 \\
1921 & 72 & 1936 & 124 \\
1922 & 95 & 1937 & 117 \\
1923 & 108 & 1938 & 121 \\
1924 & 91 & 1939 & 127 \\
1925 & 99 & 1940 & 144 \\
1926 & 96 & 1941 & 151 \\
1927 & 85 & 1942 & 142 \\
1928 & 84 & 1943 & 116 \\
1929 & 110 & 1944 & 143 \\
1930 & 82 & 1945 & 114 \\
\hline
\end{tabular}

Source: $\mathrm{MOH}$ Annual Reports, Exeter

Table 3

Cancer Deaths (per million of population)

\begin{tabular}{llll}
\hline Local Authority & $\begin{array}{l}\text { Last } \\
\text { statistics* }\end{array}$ & $\begin{array}{l}\text { Cancer } \\
\text { deaths }\end{array}$ & Notes \\
\hline Halifax County Borough & 1929 & 1700 & \\
Exeter County Borough & 1929 & 1777 & County Borough average 1929=1441 \\
Devon County Council & Not stated & Not stated & Comment on the high rate of cancer deaths \\
Cornwall County Council & 1929 & 1558 & In 1927=1760 \\
\hline
\end{tabular}

*Date of last recorded statistics (Halifax date selected for comparison). $\quad{ }^{\dagger}$ Per million of population. Sources: Table 1 above; Public Health Survey, 1930; and Public Health Survey, 1931.

death rate. Officials from the Ministry of Health shared the local MOH's concern about excessive and premature deaths (not necessarily due to cancer), and by explaining these in terms of adverse climatic conditions, a problematic urbanindustrial legacy, poor diet and inadequate medical services they did much to stimulate further municipal enterprise. ${ }^{67}$

\footnotetext{
${ }^{67}$ Halifax PH survey, sections on "general character and resources" (paragraphs 1-24); "vital
}

statistics"; and institutional accommodation (paragraphs 855-973). 


\section{Joseph Melling and Pamela Dale}

There were contemporary concerns and discussions about cancer deaths in the southwest, though only the royal dockyard town of Plymouth responded in terms which were comparable to those of Halifax. The Plymouth MOH, Dr O Hall, had noted in 1914 that his city's 230 cancer deaths represented 7 per cent of all mortality, and he predicted that one in nine women (and one in fourteen men) who lived beyond thirty-five years would subsequently develop cancer. Hall drew a parallel with tuberculosis in recommending preventive and "practical" sanitary procedures to combat the scourge, pressing for the better education of families and friends through local health visitors who could advise on the benefits of "cleanliness and the liberal application of antiseptics", for even inoperable cancer cases. ${ }^{68}$ Clearly he offered little beyond advice, though his remarks implied an incremental expansion of provision within and alongside existing municipal services under the direction of the $\mathrm{MOH}$.

It appears that the concern and recommendations of local MOHs in regard to early cancer treatment increased in parallel with the growth of specialist research and amenities during the inter-war years. But they exhibited a customary reflex in their continued scrutiny of local health statistics and "practical observation" gathered by local authority staff and hospital doctors. Local knowledge and institutional experience confined as well as sustained their commitment to addressing the question. In pursuing their own investigations into cancer cases, MOHs displayed a significant concern with domestic family life within the larger context of environmental and public health. In the absence of a clinical consensus on the environmental causes of cancer, medical officers in towns such as Halifax often used their annual reports to ruminate expansively on possible relationships between climate and health as well as the impact of industrial occupations, employment patterns, urban lifestyles, nutrition, smoking, and family income on rates of morbidity and mortality. ${ }^{69}$ Dr Cyril Banks suggested that oral cancers might be linked to "constant irritation such as may be caused by ill-fitting false teeth or by excessive smoking", ${ }^{70}$ while "constant irritation" of the body was another frequent suggestion by those seeking to explain the growth of skin tumours. A more sustained contribution to debates on epitheliomas among industrial workers came with the Darwen MOH's investigation of scrotal cancer among Lancashire cotton operatives. While linking the potential harm caused by lubricating oil and high working temperature to the remarkable increase of tumours among male cotton spinners in the early twentieth century, he also identified hygiene, dress and posture as contributing factors. ${ }^{71}$

The vigorous exchanges which surrounded research on the carcinogenic properties of carbon mineral oils that swept Lancashire in the 1920s attracted unusual attention among local MOHs. Males were less prominent than females in the annual discussions of cancer which figured in $\mathrm{MOH}$ annual reports before 1940. Services for men appear to have been less organized. Efforts to address male cancers do not

\footnotetext{
${ }^{68}$ Plymouth and West Devon Record Office, 1363/10 County Borough of Plymouth, Medical Officer of Health annual reports, 1914, pp. 42-3.

${ }^{69}$ An approach endorsed by Ministry of Health officials. Halifax PH survey, paragraphs $1-24$.
}

\footnotetext{
${ }^{70}$ Halifax MOH report for 1925 , pp. 14-15.

${ }^{71}$ NA, PIN 12/33, 'An enquiry in regard to the cause of spinners' scrotal cancer', by James Robertson, MB, DPH, Medical Officer of Health, Darwen, March 1926.
} 
seem to have attracted the commitment from male doctors noticeable in women doctors treating female cancer patients. ${ }^{72}$ Patients presenting lung pains or coughs when attending the tuberculosis dispensary, or skin tumours when seeking advice at a venereal disease clinic, would be recommended to visit a general practitioner. Men's opportunities for specialized examination depended to a large degree on access to panel doctors under Britain's national insurance scheme. Trade unions in hazardous trades were increasingly sensitive to the risks of industrial cancers by the 1930s, though even here the effective diagnosis of disease depended on the availability of expertise and the enthusiasm of the local medical community (including MOHs) for targeted treatment and prevention. ${ }^{73}$

The unequal attention devoted to female and male cancers is surely explained, in part, by an impressive international research effort on female cancers undertaken during the early twentieth century. ${ }^{74}$ Groups concerned with the surgical and alternative treatments of female cancers also drew strength from the persistence of late-Victorian "maternalist" values and the eugenics debates of the pre-1914 period, which promoted concerns with women's welfare at the workplace as well as in domestic life. ${ }^{75}$ The practical mechanisms by which maternal illnesses were detected, however, depended on the institutional structure of municipal government and the priorities set by MOHs within the limits of civic budgets. Arrangements made for female sufferers were so effective largely because municipal services dedicated to the care of noncancer patients brought individuals under observation and treatment which enabled medical staff to recognize cancer symptoms.

The development of services provided by women for women, seen by some contemporaries as a way of encouraging clinic attendance, allowed female doctors to gain employment in these facilities as well as access to training opportunities unavailable to male colleagues. ${ }^{76}$ In Halifax, for example, only women were employed in the council's maternity clinics and the voluntary sector birth control clinic, which were the key sites for cancer prevention and diagnosis. ${ }^{77}$ Evidence from this town

\footnotetext{
${ }^{72}$ Moscucci, both references, note 24 above. An emphasis on services provided by women for women helps explain close links between some family planning clinics and gynaecological clinics which potentially provided another source of cancer referrals. Audrey Court and Cynthia Walton, 1926-1991: Birmingham made a difference. The Birmingham Women's Welfare Centre: the Family Planning Association in Birmingham, Birmingham, Barn Books, 2001, pp. 11-17.

${ }^{73}$ Pamela Dale, Janet Greenlees and Joseph Melling, 'The kiss of death or a flight of fancy? Workers' health and the campaign to regulate shuttle kissing in the British cotton industry, c.1900-52', Soc. Hist., 2007, 32: 54-75.

${ }^{74}$ Reagan, op. cit., note 25 above.

${ }^{75}$ Carolyn Malone, Women's bodies and dangerous trades in England, 1880-1914, Woodbridge, Boydell Press, 2003; Barbara Harrison, Not only the 'dangerous trades': women's work and
}

health in Britain, 1880-1914, London, Taylor and Francis, 1996.

${ }^{76}$ For debates regarding benefits of specialism and separatism, see Rosemary Stevens, Medical practice in modern England: the impact of specialization and state medicine, New Haven, Yale University Press, 1966, pp. 38-52; Louise Westwood, 'Separatism and exclusion: women in psychiatry, 1900-1950', in Pamela Dale and Joseph Melling (eds), Mental illness and learning disability since 1850: finding a place for mental disorder in the United Kingdom, London, Routledge, 2006, pp. 91-111, on pp. 92-3.

${ }^{77}$ Archives and Manuscripts Collection, Wellcome Library, London, SA/FPA/A11/20, letter from Roe (Halifax MOH) to Mrs Freeth, 27 Aug. 1935 , noted that the birth control clinic was detecting gynaecological conditions. Dr Hynemann described the clinic as "health and life saving" at its 1937 AGM. Calderdale Record Office, Misc. 


\section{Joseph Melling and Pamela Dale}

confirms Moscucci's conclusions in regard to the growth of female-oriented cancer services. ${ }^{78}$ Even without the conscious advocacy of feminist practitioners, the growth of medical facilities for ante- and post-natal examination was significant from the 1930s. Thomas McKeown and C R Lowe suggest that by 1946, four in every five women confined at home were regularly attending local authority ante-natal clinics. ${ }^{79}$ Some $\mathrm{MOH}$ reports indicate less frequent attendances before 1948, though it remains clear that most pregnant (and newly delivered) women had some contact with medical services which offered scope for cancer detection. In contrast to well-documented difficulties with the School Medical Services, evidence from Halifax and Exeter reveals few obstacles to referring women with pregnancy complications from the clinics to local hospitals. $^{80}$

Unequal provision or access to cancer facilities in Halifax and Exeter should be seen against a background of limited general provision for sufferers before the 1939-45 war. Cancer was one among a number of health issues struggling for priority in the inter-war period while the stubborn persistence and steady rise in cancer deaths contributed to the fatalistic pessimism found in some quarters of the medical profession. There had been a growth of optimism in the 1920s with the adoption of radium therapy, which shrank as the limits of these techniques were exposed. This is reflected in Halifax's initial confidence about the effectiveness of its health department's role in cancer prevention, including occupational disease. By 1934 the $\mathrm{MOH}$, Dr Roe, confessed that "under present conditions the Public Health Service is doomed (so far as cancer is concerned) to a restricted field". ${ }^{81}$ Roe complained not only about the lack of notifications from local doctors and voluntary hospitals, but that he had practically no reliable information "as regards the heredity, environment, habits, treatment, and results of treatment of cancer cases". ${ }^{82}$ Privately, the Halifax authorities advised visiting ministry officials that senior local surgeons did not always act on referrals from the female medical officer at the ante-natal clinic, leading to needless fatalities even among known cases. ${ }^{83}$ It is clear that the fruits of municipal efforts were often thin. Ante- and post-natal clinics might discover cancers in the course of their examinations but did little for older women, whose greater propensity to develop cancer shapes modern screening programmes. Common cancers such as those of the stomach, bowel and mouth affected both males and females in significant numbers but institutional rules could exclude the early recognition of cancers. Patients presenting more than one set of symptoms in Devon, for example, frequently found themselves excluded from particular services. ${ }^{84}$

190:1, Halifax Women's Welfare Club/Halifax Family Planning Clinic, notebook of minutes 1934-1938.

${ }^{78}$ Moscucci, both references, note 24 above.

${ }^{79}$ Thomas McKeown and C R Lowe, An introduction to social medicine, 2nd ed., Oxford, Blackwell, 1974, p. 287.

${ }^{80}$ David Hirst, 'The early school medical service in Wales: public care or private responsibility?', in A Borsay (ed.), Medicine in Wales c. 1800-2000: public service or private commodity?, Cardiff, University of Wales Press, 2003, pp. 65-85.

${ }^{81}$ Halifax MOH report for 1934 , p. 7.

${ }^{82}$ Ibid.

${ }^{83}$ Halifax PH survey, paragraph 287.

${ }^{84}$ Pamela Dale, 'Tension in the voluntarystatutory alliance: "lay professionals" and the planning and delivery of mental deficiency services, 1917-1945', in Dale and Melling (eds), op. cit., note 76 above, pp. 154-78, on p. 168. 
Britain's Ministry of Health possessed limited financial and political resources in its early years and offered little advice in such circumstances. Nor was it always consistent. While encouraging co-operation with the local medical community, the Ministry also stressed the value of seeking to recruit better qualified physicians and surgeons from outside provincial industrial towns such as Halifax to fill municipal posts. ${ }^{85}$ The Ministry appeared to offer a counsel of perfection in such instances, though it is fair to note that one reason why Halifax developed better services was the Ministry's adjudication favouring the Corporation by allowing the borough council to appropriate Poor Law hospital facilities that had previously served parts of the West Riding of Yorkshire. ${ }^{86}$ Whether London officials recognized the full consequences of such policies, these decisions enabled local MOHs to apply for Ministry support to utilize these facilities and free beds at local infirmaries (such as the RHI) to provide an improved cancer service. ${ }^{87}$

We have noted that MOHs hoping to overcome financial and institutional constraints could expect little funding or political support from central government. Their outlook and activities were influenced by London officials but after 1919 the new Ministry of Health rarely directed local authorities to undertake particular programmes of investment for cancer prevention and treatment. Ministry officials acknowledged the limits of provision in their periodic surveys of health care across the regions, and the Ministry's Departmental Cancer Committee sought to both recognize and focus local activities, prompting a number of public education initiatives. ${ }^{88}$ But the slow progress of facilities reflected, in part, the political weakness of health ministers who were not members of the Cabinet and faced powerful resistance from the Treasury and rival departments. ${ }^{89}$ The reports of the MOHs usually made few direct references to gender in this regard, expressing rather a broad concern with the general health of the local population. It is in the provisions, priorities and practices of local government that visible lines of difference arise in the way that diseases, including cancers, were gendered. Such distinctions were also, we have suggested, embedded in the relationships formed and conducted between voluntary and statutory agencies, and among the professional groups within the medical profession with whom the MOHs dealt in co-ordinating services for a population with a diverse range of health problems.

In the final part of this article we consider the responses of British government institutions and their medical advisers to the challenge of cancer in the contrasting cases of industrial workers and military pensioners, where the patients affected were usually (and in the military case almost invariably) male.

\footnotetext{
${ }^{85}$ Halifax PH survey, paragraphs $925-6$ and 994-5.

${ }^{86}$ NA, 66/289, Yorkshire (WR)

CC - LGA, 104 PH Survey 1934

(hereafter WRCC PH survey), paragraphs 87 and 120.
}

\footnotetext{
${ }^{87}$ Halifax PH survey, paragraphs 1080 and 1099-1100.

${ }^{88}$ John Welshman, Municipal medicine: public health in twentieth-century Britain, Oxford, Peter Lang, 2000, p. 258.

${ }^{89}$ Harris, op. cit., note 34 above, pp. $178-80$.
} 


\section{The Claims of Cancer: Government Responses to Cancer Compensation for Industrial and Military Casualties}

In the early years of the twentieth century it was rare for cancer to be considered as an injury which arose from service in the employment of a private company or public enterprise. The links between industrial or military materials and the carcinogenic properties of manufacturing processes or weaponry for warfare were largely undiscovered on the outbreak of the 1914-18 war. Occupational diseases had been linked to particular trades and tasks since at least the early modern period, even where the agent of injury or disease did not exclusively or even properly belong to that pursuit. Not only were specific occupations identified as distinctly hazardous but dangers were also attached with work which was identified, even if inaccurately, with one gender or age group. Injuries which resulted in a loss of (usually male) earnings for a family as well as an individual wage-earner provided a rallying point for British compensation reformers as well as trade unions in the decade after 1896, thereby tying compensation campaigns to male-dominated labour organizations. ${ }^{90}$ It was in the growing perception that certain cancers were associated with particular civilian and military hazards which endowed them with a distinctively male profile, affirming a gendered approach to bodily risk, injury and income loss during the inter-war period.

The deliberations which followed the claim of compensation for cancer resulting from industrial and combat injuries rarely involved Medical Officers of Health. Their contribution highlights something of the medical and financial priorities of both central and local government in tackling male-associated cancers. The evidence surveyed here suggests that central government departments approached the occupational cancer problem in terms which would have been familiar both to local government officers and to the medical advisers of British industry: namely, the primary need to protect employment and resources while acknowledging that male cancers linked to work and active service would attract significant compensation claims. Medical evidence inevitably became part of the disputations around the nature, extent and impact of cancer illness where monetary maintenance was decided on legal or quasi-legal terms. In this context, the provisions made for male cancer sufferers were affected by a range of institutional structures and were constrained by rules which different agencies introduced.

The distinctive ways in which industrial cancer affected men and reinforced gendered approaches to the disease can be seen in responses to the carcinogenic properties of the mineral oils used to lubricate machines in British manufacturing. This machinery included the cotton spinning frames which came into physical contact with the abdomen and groin of the male machine minders. The result of this persistent, intimate movement was the development of scrotal epitheliomas in a number of spinners. S R Wilson, a surgeon at Manchester's Royal Infirmary (MRI), was the

\footnotetext{
${ }^{90}$ One example is anthrax, widely known as “wool sorters' disease". Ian Mortimer and Joseph Melling, "The contest between commerce and trade, on the one side, and human life on the other": British
}

government policies for the regulation of anthrax infection and the wool textiles industries,

1880-1939', Textile Hist., 2000, 31 (2): 223-37. 
first to investigate scrotal cancer among cotton spinners in the Edwardian period, before undertaking joint research with A H Southam. Their work on 141 patients, published in the British Medical Journal in 1922, suggested a possible link between the scrotal warts previously associated with chimney sweeps exposed to carbon dust, and the usage of mineral oils which had progressively replaced vegetable fats as lubricants from the 1860s. ${ }^{91}$ This article galvanized the Home Office and its factory inspectorate into more thorough investigation and recording of cases. The fifteen casualties reported among spinners in 1922-23 rose to seventy-nine the following year, precipitating the appointment of a Departmental Committee under Gerald Bellhouse to consider practicable methods of protecting operatives. ${ }^{92}$ The committee's secretary, Dr S A Henry, personally conducted research into more than 500 cases and was an early convert to the theory of mineral oil pathology amid the competing claims of bodily heat, tight and dyed clothing, and masculine disregard for cleanliness. Bellhouse also considered the work of laboratory-based experts like Archibald Leitch and others, who were investigating the carcinogenic properties of tars, as well as the holistic explanation offered by James Robertson, MOH for Darwen. ${ }^{93}$

The committee reached somewhat tepid conclusions that voluntary medical examinations should be trialled and splash guards fitted while safer lubricants were being sought. The emphasis placed on detailed laboratory research tended to exclude local health officials. MOHs had maintained a precarious position in regard to industrial health but made little specialist contribution beyond Veitch Clark's leading role on the Manchester Cancer Committee. ${ }^{94}$ Another factor restricting the scope of MOHs to intervene in such controversies was the clear determination of the Home Office's factory inspectorate to regain the initiative in regard to hazardous working conditions in the 1920 s. $^{95}$ Their approach served to narrow the focus of official attention to the threat represented by oil to the groin of the highly-unionized senior male spinners, whose spokesmen enjoyed close contacts with the Factory Department. The MOHs did not and looked to the Ministry of Health to advance their cancer work and claims to specialist knowledge and expertise.

\footnotetext{
${ }^{91}$ E M Brockbank, Mule spinners' cancer: epithelioma of the skin in cotton spinners, London, H K Lewis, 1941, pp. 5-7, for a brief synopsis of work by Wilson, Southam and other researchers. See also A H Southam, 'Mule-spinners' cancer', in Manchester Committee on Cancer, Lectures on cancer, Manchester, Blacklock, 1927, pp. 103-7. Southam favoured early surgery.

${ }^{92}$ Report of the Departmental Committee appointed to consider evidence as to the occurrence of epitheliomatous ulceration among mule spinners [Bellhouse Committee Report], London, HMSO, 1926.

${ }^{93}$ The work of the committee and its conclusions are summarized by Brockbank, op. cit., note 91 above, pp. 5-10.

${ }^{94}$ Manchester University provided the laboratory facilities and its control of the MCC increased
}

noticeably after 1930 , though $\mathrm{R}$ Veitch Clark, S A Henry and E M Brockbank (the last chairing Manchester's branch of the British Empire Campaign) all retained a presence on its Consultative Committee. Report of the MCC for the years 1925 1926 and 1927, pp. 2-5. Copies in John Rylands Library, Manchester University. For the Lancashire MOHs, see Janet Greenlees, "'Stop kissing and steaming!": tuberculosis and the occupational health movement in Massachusetts and Lancashire, 1870-1918', Urban Hist., 2005, 32: 223-46.

${ }^{95}$ The division of responsibilities between the Factory Department of the Home Office and the new Ministry of Health was a source of frustration for senior officials who wanted to extend their work into the field of factory hygiene. See Arthur Newsholme, The Ministry of Health, London, G P Putnams Sons, 1925, pp. 114-25. 


\section{Joseph Melling and Pamela Dale}

While MOHs in industrial towns such as Halifax and county centres such as Exeter looked to the Ministry of Health for guidance, the latter's capacity for intervention in health questions was restricted by legal and financial requirements as well as a scarcity of funding in these years. ${ }^{96}$ Such restrictions became apparent in its dealings with the Treasury and also in the handling of cancer cases by the Ministry of Pensions (MP). ${ }^{97}$ This ministry acquired a reputation for strict fiscal scrutiny as it deflected demands for improved pension benefits and better services towards the voluntary organizations which supported service personnel after the 1914-18 war. ${ }^{98}$ MOHs had long experience of such voluntary organizations and sometimes appropriated the facilities designed for former service personnel. ${ }^{99}$ By the 1930s, the MP was increasingly concerned about claims from cancer sufferers among its pensioners and potential pensioners. Whereas maternal health and welfare attracted significant interest from both doctors and activists throughout this period, there was a different but widespread and sustained sympathy for men who had been injured in the service of their country. Doctors diagnosing the late development of cancers in male patients appear to have shared these sentiments, or at least responded to them.

Pensions Ministry officials accepted the possibility of cancers developing from former war injuries, confirmed by medical experts, but were concerned at the growing number of claims from personnel who had not originally merited a pension. ${ }^{100}$ The Ministry was also alarmed at the links made between cancer, gas attacks and even the gastrointestinal problems common in military service. The generosity of medical support is indicated in the complaint of one government medical officer that extending entitlements to include those who claimed to be suffering from "late developing malignant condition is in the majority of cases, a gesture in favour of the pensioner for which I can find inadequate medical justification". ${ }^{101}$ The Medical Research Council (MRC) recognized the tension between forensic proof and public sympathy in a memorandum on the subject in $1937 .{ }^{102}$ One doctor noted,

... our main problem being the relation of trauma to malignant growth and the chief difficulty was that whereas medical evidence of direct association between trauma and new growth was very slight, the belief of the lay public, supported at times by individual doctors, was that

\footnotetext{
${ }^{96}$ Cancer services are discussed in WRCC PH survey, paragraphs $73-5$. Comments by ministry officials, drawing attention to recent circulars, were apparently designed to support the newly appointed $\mathrm{MOH}$ who was struggling to impose his authority and expand services against resistance from senior lay council officials.

${ }^{97}$ One cause for caution was the 500,000 disability pensions the Ministry paid by 1938 . Lyn MacDonald, The roses of no man's land, Harmondsworth, Penguin, 1993, pp. 303-4.

${ }^{98}$ Jeffrey S Reznick, Healing the nation: soldiers and the culture of caregiving in Britain during the Great War, Manchester University Press, 2004, pp. ${ }_{99}^{128-9 .}$

${ }^{99}$ The care of Halifax veterans suffering from tuberculosis was a heavy duty for the tuberculosis officer. Halifax CB minutes 1925-26, Health
}

Committee 21 July 1926, p. 1225. On the other hand, the sanatorium at Tehidy Park was provided by the Cornish War Memorial Committee. Cornwall PH survey, p. 32.

${ }^{100}$ NA, PIN 15/4041, Medical Research Council, 'Cancer arising in pensioners and ex-servicemen', 26 Nov. 1937, preamble explains that the Memorandum had been prepared following the Ministry of Pensions' request for advice "as to the present state of knowledge bearing on the question of the possible role of previous war injuries in the causation of malignant growths". It followed a conference held on 12 Nov. 1937.

${ }^{101}$ NA, PIN 15/4041, letter from C R Stewart (copy to DGMS), 29 July 1937.

102 'Cancer arising in pensioners and ex-servicemen', op. cit., note 100 above. 
direct connection existed and particularly was the belief strongly held if the trauma was due to war service. ${ }^{103}$

The Ministry of Pensions established the principle that only cases with a "long standing history of inflammation" were admitted as pension-worthy. Such patients included those suffering a carcinoma arising directly from a gunshot wound, malignancy of a gastric ulcer, ulcer of the bowel following a continuous history of dysentery, or a sarcoma "in the site of an old compound fracture". ${ }^{104}$ At the same time MP officials stressed the lack of statistical proof that ex-service men were more prone to cancers than the general population. An investigation conducted by the MRC at the request of the Ministry also reported that the "vast majority" of traumatic lesions did not result in cancers and that the majority of cancer sufferers similarly had no history of injury or any "specific forms of chronic irritation". ${ }^{105}$ These conclusions challenged the popular assumption, which the Halifax MOHs had used as the starting point for their hints on cancer, that male cancers were commonly associated with constant irritation. ${ }^{106}$ In commissioning such research the Ministry was seeking to combat what its officials saw as the inclination of cancer patients "to incriminate some outside factor or agency and to exonerate their own constitutions". 107

In striving to shift the burden of a cancerous constitution on to the male patient, MP officials and some of their medical advisers were reverting to a familiar axiom in compensation law: that the individual must bear some responsibility for assessing the risks which he (or more rarely she) faced in hazardous occupations and in preserving their own health outside the workplace. The scepticism of the Ministry stood in contrast to the growing recognition of the carcinogenic properties of materials associated with industrial cancer, more specifically where the skin was chronically irritated and exposed to toxic materials. The Factory Department of the Home Office also publicized the responsibility of individual workers for maintaining personal hygiene and inspecting themselves for any signs of scrotal irritation or other symptoms of skin cancer: this recommendation was reached after stubborn resistance from both employers and operatives to compulsory medical examination. Most official efforts were devoted to ensuring effective preventive measures such as the introduction of safer "Twort" oils, though again business concerns at the costs of re-equipping plant slowed progress. ${ }^{108}$ Factory reports documenting "mule spinners' cancer" provided one of the few avenues for active discussion of cancers affecting men in the inter-war years, though in truth women and less skilled males were also exposed to harmful oils.

\footnotetext{
${ }^{103}$ NA, PIN 15/4041, Report on conference between Medical Officers of the Ministry of Pensions and representatives of the Medical Research Council, 12 Nov. 1937, comments attributed to Dr Hebb.

${ }^{104}$ NA, PIN 15/4041, letter from J H Hebb to Sir Edward Mellanby, MRC, 8 Oct. 1937.

105 'Cancer arising in pensioners and exservicemen', op. cit., note 100 above, section A, paragraphs 1-2.
}

\footnotetext{
${ }^{106}$ Halifax MOH report for 1925, pp. 14-15.

107 'Cancer arising in pensioners and ex-servicemen', op. cit., note 100 above, section B, paragraph 3 .

${ }^{108}$ NA, LAB15/151, undated pamphlet (c. 1943?) 'Mule spinners' cancer: a paper of great importance', Manchester, The Manchester Oil Refinery, reviews the research and chronology of government responses.
} 


\section{Joseph Melling and Pamela Dale}

Whereas MP officials and their political masters sought to prevent public sympathy for ex-servicemen spilling over into wasteful generosity to cancer victims, the Factory Department could display greater concern for workers in the knowledge that the Treasury would be less hostile to compensation costs carried by private industry. The greater proximity of the factory inspectorate to the contemporary workplace and the opinions of labour organizations in regard to industrial injury and illness strengthened the hand of more sympathetic Home Office officials in dealings with employers. Whether sympathetic or unsympathetic, however, the powerful presence of different ministries in the settlement of cancer compensation cases only exposed the limits of the Health Ministry's influence over the research and administrative systems which directly affected cancer sufferers.

\section{Discussion: Public Health Authorities, Cancer Services and Gender Issues}

In recent years medical historians have published substantial research on the diagnosis and treatment of cancer. Pinell emphasized the degree to which cancer care was subject to a form of cost-benefit analysis in which the risks and remedies were weighed by decision makers and even some medical personnel. ${ }^{109}$ Bernard Harris has noted how increasing concern about cancer in inter-war Britain was fed by a changing "profile of ill-health mortality" amid rising health expectations, as well as scientific and therapeutic innovation. ${ }^{110}$ Significant interest has also been shown in the distinctive experience of female patients struggling to secure medical care and greater freedom of choice in fighting the disease. In this brief survey of public health provision during the early twentieth century we have considered the different ways in which cancer was gendered and how the experiences of women and men suffering from the disease diverged during these years. Our research suggests that impressions of femininity and masculinity were embedded in administrative practices as well as guiding the behaviour of key actors.

In exploring difference and inequality in Britain's cancer services before the 1940s we have concentrated on the role of public officials and particularly the local Medical Officers of Health. Few case studies of public health services in the locality have addressed the cancer question. The MOH's role in cancer provision has received little attention from historians. This neglect is understandable but significant, as local cancer services reflected the breadth and complexity of his concerns though they usually appeared at the lower end of a long agenda of duties. We have compared an established industrial centre in the West Riding with the historic capital of Devon to draw out something of the varied and peculiar concerns of the $\mathrm{MOH}$ with cancer in our period. Extending the discussion of public services beyond our regional case studies, we also examined the limited role that they, and even their political superiors at the Ministry of Health, could play in the risk-benefit deliberations which

\footnotetext{
${ }^{109}$ Pinell also notes the difficulties of preserving an "official oncology" in the inter-war period, op. cit., note 1 above, p. 680 .
}

${ }^{110}$ Harris, op. cit., note 34 above, pp. $220-1$. 
accompanied the assessment of the medical and compensation needs of those injured at the workplace and in military service.

In discussing the institutional processes involving cancer care, we have identified inequalities which arose in provision for patients at local and national levels. The influence of gender (and more accurately constructions of gender), can be seen not only in the bias of professional research and the priorities outlined by national governments but also in the configuration of central and local institutions dedicated to the protection of public health. Scientists involved in cancer research, and doctors providing care for patients, stressed the susceptibility of women to particular forms of cancer and the need for a range of treatments including surgical intervention. MOHs employed by local authorities rarely displayed an overt bias in their commitment to serving females in cancer services but the logic of the services which developed under their charge led, inexorably if indirectly, to unequal opportunities for cancer diagnosis and treatment. We suggest that such medical arrangements were themselves inscribed with ethical and social preferences concerning the value of motherhood and the responsibilities of men to serve industry and their country.

The unbalanced character of local cancer services overseen by the MOH has to be understood within the sharp fiscal and institutional constraints on these officers and governments more generally during the early twentieth century. In important respects, Britain failed to match the standards of health care reached in other countries. ${ }^{111}$ Despite obvious inadequacies in the services which MOHs could provide for both men and women in these years, they may have vigorously promoted what Pinell terms the "social illusion" of the efficacy of diagnosis and early treatment, making the fight against cancer more credible. ${ }^{112}$ Amid the fatalism evident in MOH annual reports during the 1930s, some officers promoted health education campaigns which implied the possibility of curbing the scourge of cancer. In practice, as the limited fruits of expensive specialist research indicated, grand schemes of preventive measures were hardly likely to show impressive returns for scarce resources. ${ }^{113}$ Indeed there are few signs of pioneering schemes in our case studies, but there is clear evidence of continued fragmentation and organizational rivalries in south-west England, which MOHs found difficult to surmount.

In concluding that the MOHs were able to exert only a limited influence over the development of cancer services in these years, we suggest that women's role as mothers gave them an opportunity for rudimentary examination that rarely existed for men outside military service in their younger years. ${ }^{114}$ The knowledge and experience amassed by the MOHs came in the context of a dismal catalogue of failure in cancer cases. In some instances, however, as at Manchester, dynamic MOHs could resist the marginalization of their role as cancer treatment became the province of specialist laboratory

\footnotetext{
${ }^{111}$ Sheard and Donaldson, op. cit., note 36 above, pp. 27, 195; Harris, op. cit., note 34 above, p. 220.

${ }^{112}$ Pinell op. cit., note 1 above, pp. $680-1$.

${ }^{113}$ Investment in expensive treatment facilities yielded limited results unless patients presented themselves for medical examination and doctors
}

improved diagnoses and treatment. In the hands of non-specialists, radium therapy could pose a threat to patients. Harris, op. cit., note 34, p. 221, for summary.

${ }^{114}$ David Silbey, 'Bodies and cultures collide: enlistment, the medical exam and the British working class, 1914-1916', Soc. Hist. Med., 2004, 17: 61-76. 


\section{Joseph Melling and Pamela Dale}

research and dedicated hospital practice. Debates about the responsibility for cancer again arose in discussions of industrial and military compensation where officials battled to protect the fiscal integrity of the liability awards to men (and more rarely women) injured in the course of their duties. The lesson of the struggles for better treatment and compensation during these difficult years was that strategic advances could be made by both women and men on specific fronts but that partial initiatives frequently militated against a coherent national programme for cancer care that left both sexes poorly served by their public authorities. 